\title{
EXPRESSION OF PROHIBITION AS A REPRESENTATION OF TABOO IN BADUY SOCIETY
}

\author{
Dase Erwin Juansah \\ Universitas Sultan Ageng Tirtayasa \\ email: daseerwin77@untirta.ac.id
}

\begin{abstract}
The use of prohibited expressions as a taboo representation is a linguistic and cultural fact that is always present in every society. The taboo expression is considered to have a moral message for people who believe in it. This study aims to describe the expression of prohibition (pamali) as a taboo representation in the Baduy community. The study used a qualitative approach with an ethnographic method with an anthropolinguistic design. The source of the research data gives the informant's oral utterances in natural speech situations and what they are. Data collection is conducted with involved participation techniques, observations, and interviews. Analysesare carried out during collection, reduction, presentation, and drawing conclusions/verification. Data analysis is inductive-qualitative. The study found that the prohibition expression in the Baduy community can be classified into three categories. First, the prohibited expressions are relatted to the management of agricultural land, including: (a) the time to start farming, (b) the process of farming, and (c) the time of harvesting rice in the fields. Secondly, the prohibition is related to the rules of the community life, including: (a) that the rules of life are personal, and (b) that the rules of life are general. Third, the prohibition expressions are related to the use of forest resources and the environment including: (a) rules relating to entrusted forests, and (b) rules for tillage. In general, the prohibition expressionsuse imperative forms, both orders and prohibitions.
\end{abstract}

Keywords: expressions of prohibitions, taboos, prohibition imperatives, prohibition orders, Baduy community

\section{UNGKAPAN LARANGAN SEBAGAI REPRESENTASI TABU PADA MASYARAKAT BADUY}

\begin{abstract}
Abstrak
Penggunaan ungkapan larangan sebagai representasi tabu merupakan fakta linguistik dan budaya yang selalu ada dalam setiap masyarakat. Ungkapan tabu dianggap memiliki pesan moral bagi masyarakat yang meyakininya. Penelitian ini bertujuan mendeskripsikan ungkapan larangan (pamali) sebagai representasi tabu di masyarakat Baduy. Penelitian menggunakan pendekatan kualitatif dengan metode etnografis berancangan antropolinguistik. Sumber data penelitian adalah tuturan lisan informan dalam situasi tutur yang alamiah dan apa adanya. Pengumpulan data dengan teknik partisipasi terlibat, pengamatan, dan wawancara. Analisis dilakukan selama pengumpulan, reduksi, penyajian, dan penarikan simpulan/verifikasi. Analisis
\end{abstract}


data bersifat induktif-kualitatif. Penelitian menemukan bahwa ungkapan larangan pada masyarakat Baduy diklasifikasikan menjadi tiga kategori. Pertama, ungkapan larangan berkaitan dengan pengelolaan lahan pertanian, mencakup: (a) waktu mulai berladang, (b) proses berladang, dan (c) waktu panen padi di ladang. Kedua, ungkapan larangan berkaitan dengan aturan hidup bermasyarakat, mencakup: (a) aturan hidup bersifat pribadi, dan (b) aturan hidup bersifat umum. Ketiga, ungkapan larangan berkaitan dengan pemanfaatan sumber daya hutan dan lingkungan, mencakup: (a) aturan berkaitan dengan hutan titipan, dan (b) aturan pengolahan tanah. Secara umum, ungkapan larangan menggunakan bentuk imperatif, baik perintah maupun larangan.

Kata kunci: ungkapan larangan, tabu, imperatif larangan dan perintah, masyarakat Baduy

\section{PENDAHULUAN}

Komunikasi merupakan kebutuhan yang sangat mendasar bagi manusia. Kegiatan tersebut dapat dilakukan dengan berbagai cara, mulai dari gerakan tubuh, dengan mimik muka atau dapat pula dengan menggunakan alat. Alat komunikasi yang utama bagi manusia adalah bahasa. Selain sebagai alat komunikasi, bahasa juga dijadikan sebagai alat pengembang kebudayaan dalam mewariskan budaya pada generasi berikutnya (Koentjaraningrat, 2009).

Sama halnya dengan bahasa, kebudayaan dipelajari, ditransmisikan, dan diwariskan dari generasi ke generasi berikutnya melalui perbuatan dan melalui komunikasi. Hubungan bahasa dan kebudayaan sangat erat, keduanya saling mengisi dan memengaruhi. Dalam realitasnya, bahasa tidak bisa dilepaskan dari faktor sosial dan budaya masyarakat penuturnya (Mardikantoro, 2016). Oleh karena itu, perwujudan suatu bahasa sangat dipengaruhi oleh latar belakang sosial budaya masyarakat penutur bahasa tersebut (Kridalaksana, 2007).
Chaer (2009) mengungkapkan bahwa hubungan antara bahasa dan kebudayaan merupakan hubungan yang subordinatif, yaitu bahasa berada di bawah lingkup kebudayaan. Hubungan bahasa dan kebudayaan merupakan dua buah fenomena yang terikat, bagai sekeping mata uang yang pada satu sisi berupa sistem bahasa dan pada sistem yang lain berupa sistem budaya. Apa yang tampak dalam budaya akan tercermin dalam bahasa. Sebaliknya,apa yang tampak dalam bahasa akan tercermin dalam budaya. Setiap pengguna bahasa hidup dan bergerak dalam lingkungan masyarakat yang memiliki adat istiadat atau tata cara yang berbeda-beda. Perbedaan tersebut terwujud pula dalam penggunaan bahasa (Fallo \& Rokhman, 2016).

Kajian mengenai hubungan antara bahasa dan kebudayaan umumnya dilihat dari ilmu yang mempelajarinya, yakni antropolinguistik. Seperti kita ketahui, antropolinguistik adalah cabang linguistik yang mempelajari variasi dan penggunaan bahasa dalam hubungan dengan perkembangan waktu, perbedaan tempat komunikasi, sistem keke- 
rabatan, pengaruh kebiasaan etnik, kepercayaan, etika berbahasa, adat istiadat, dan pola-pola kebudayaan lain dari suatu suku bangsa.

Banyak hal yang dapat diteliti mengenai hubungan antara bahasa dan budaya, salah satu diantaranya adalahtabu. Tabu memegang peranan penting dalam bahasa. Masalah tabu sering dikaitkan dengan ilmu semantik karena tabu dianggap sebagai penyebab berubahnya makna kata (Sumarsono, 2012). Lebih lanjut, Sumarsono (2012) menjelaskan bahwa sebuah kata yang ditabukan biasanya tidak dipakai, kemudian digunakan kata lain yang sudah memunyai makna sendiri dan akibatnya kata yang tidak ditabukan itu memperoleh beban makna tambahan.

Tabu di setiap daerah di Indonesia memiliki konsep yang berbeda-beda. Di lingkungan masyarakat Sunda, tabu sering disinonimkan dengan kata $p a-$ mali, artinya larangan karuhun 'nenek moyang' atau leluhur'. Di lingkungan masyarakat Minangkabau, tabu diistilahkan dengan kata pantang. Sementara itu, tabu di lingkungan masyarakat Muna diistilahkan dengan kata falia. Mondolala (2015) menjelaskan bahwa falia muncul sebagai bentuk kearifan lokal masyarakat Muna yang tidak menghakimi atau memarahi langsung seseorang atas tindakannya.Hal ini dilakukan demi menjaga perasaan dan harga diri seseorang yang melakukan kesalahan fatal. Dengan demikian, dapat dipahami bahwa tabu merupakan ekspresi masyarakat atas pencelaan terhadap sejumlah tingkah laku atau ucapan yang dipercayai dapat memberikan dampak buruk pada anggota masyarakat, baik karena alasan-alasan kepercayaan maupun karena perilaku atau ungkapan tersebut melanggar nilai-nilai moral.

Tabu erat hubungannya dengan berbagai aspek kehidupan, seperti budaya, keyakinan, dan kepercayaan yang bertolak dari tradisi dan kebiasaan yang berlaku dalam kehidupan masyarakat. Berkenaan dengan hal itu, Freud (1950) menjelaskan bahwa istilah tabu (taboo) banyak digunakan di negara lain seperti Amerika, Afrika (Madagascar) Asia Utara dan Asia Tengah yang semuanya memiliki makna yang sama, yaitu pantangan, larangan dan batasan. Smith (2007) menjelaskan bahwa tabu adalah gagasan atau isu yang sangat menyiksa, mengancam, atau mempersulit dan tidak boleh dibicarakan secara terbuka. Sementara itu, Burridge \& Allan (2006) menjelaskan bahwa tabu adalah suatu perilaku yang asing dan berpengaruh pada kehidupan sehari-hari. Tabu merupakan perilaku individu yang dapat menyebabkan kegelisahan, merugikan.

Istilah yang digunakan setiap masyarakat untuk merujuk makna atau defenisi yang sama dengan tabu. Misalnya, dalam bahasa Polinesia tapu atau taboo, dalam bahasa Sandwich Islan disebut tafoo, bahasa Romawi Kuno sacer, bahasa Yunani ayos, bahasa Hebrew kodaush, bahasa Indonesia tabu atau pantangan, dan bahasa Sunda dan Banten pamali (Frazer, 1980; Freud, 1950; Huameni, 2015; Webster, 1942). Freud (1950:21) menjelaskan bahwa tabu berasal dari bahasa Polinesia yang bermakna 'pantangan atau larangan' (prohibition) atau 'batasan; (restriction). Lawan kata tabu dalam bahasa Polinisia adalah noa yang berarti sesuatu yang biasa atau lazim sehingga tidak ada larangan untuk dapat diakses atau dilakukan oleh semua orang (Humaeni, 2015). Dalam 
Dictionary of Religious, definisi tabu yaitu a restriction or ban on patent and sacred thing (Hinnels, 1984:319). Merujuk pada penjelasan tersebut, tabu merupakan sesuatu yang di larang baik dalam bentukkata-kata atau tindakan dan bagi yang melanggarnya akan mendatangkan atau mengancam jiwa (Rodman, 1988).

Beberapa penelitian telah dilakukan untuk mengkaji permasalahan tabu di masyarakat. Bakhtiar (2011) meneliti efek gender dan keformalan situasi terhadap penggunaan eufimisme dan tingkatan tabu dalam bahasa Persia. Hasil penelitian menunjukkan bahwa dalam situasi formal, baik pria maupun wanita menemukan kata-kata tabu yang mutlak tidak dapat diucapkan. Sebaliknya, dalam situasi informal, baik untuk pria maupun wanita, tidak ada kata yang dianggap tabu dan disfemistik.

Zare \& Tayyebi (2014) meneliti persepsi pembelajar bahasa Inggris sebagai bahasa kedua di Iran terhadap kata tabu, studi kasus dalam perspektif gender. Hasil penelitian menunjukkan bahwa ada perbedaan yang signifikan secara statistik dengan ukuran efek 0,3 antara peserta didik EFL perempuan dan laki-laki Iran dalam persepsi katakata tabu bahasa Inggris, yaitu pelajar perempuan EFL Iran mengambil kata-kata tabu lebih keras. Berdasarkan temuan penelitian ini, disimpulkan bahwa perbedaan gender memainkan peran penting dalam persepsi ofensif atau tidak aktifnya kata-kata tabu bahasa Inggris.

Gay \& Susanti (207) meneliti tentang pembentukan, referensi, dan latar belakang bahasa tabu dalam masyarakat Ternate. Hasil penelitian ini menunjukkan bahwa (1) bahasa tabu yang terjadi di masyarakat Ternate adalah dalam bentuk kata dasar, kata turunan, pengulangan kata, frasa, dan klausa; (2) bahasa tabu juga terjadi dalam bentuk sinonim, khususnya Bahasa Daerah Ternate (BDT) dan Bahasa Melayu Ternate (BMT). Kecenderungan individu dalam menggunakan kata-kata umpatan tidak didasarkan pada bahasa yang diperoleh, kecuali, individu bertujuan menghasilkan ekspresi tertentu berdasarkan emosi; (3) ada beberapa kata-kata umpatan yang dominan digunakan di kalangan remaja, dewasa, dan lanjut usia; (4) bahasa tabu diarahkan ke orang lain dan pembicara sendiri; (5) secara dominan, pembicara mengacu pada binatang, tumbuhan, dan bagian tubuh manusia yang tabu; (6) ada pencampuran kode antara Bahasa Daerah Ternate (BDT) dan Bahasa Melayu Ternate (BMT) serta Bahasa Indonesia (BI) dan Bahasa Ternate Ternate (BMT); (7) bahasa tabu umumnya untuk teman atau kerabat dekat atau antara pembicara dan pendengar memiliki usia yang sama. Di sisi lain, dianggap tidak sopan jika pembicara dan pendengar tidak memiliki hubungan sosial atau keduanya memiliki usia yang berbeda. Singkatnya, bahasa tabu umumnya digunakan oleh pembicara dan pendengar dengan usia yang sama dan memiliki hubungan dekat.

Humaeni (2015) meneliti tentang tabu yang berkaitan dengan perempuan pada masyarakat Banten. Penelitian $\mathrm{Hu}-$ maeni (2015) menghasilkan simpulan sebagai berikut. Pertama, keberadaan tabu perempuan pada masyarakat Banten, meskipun mereka akui sangat tidak logis dan tidak rasional, namun melanggar apa yang ditabukan oleh budaya mereka menjadi suatu hal yang 
sangat dihindari. Kedua, tabu perempuan pada masyarakat Banten memiliki fungsi sebagai bentuk penjagaan moral dan perilaku, memperkuat hubungan emosional, bentuk perlindungan, dan simbil cinta kasih.

Pemahaman tentang tabu dapat dikaitkan dengan dua kategori umum, yakni masyarakat primitif dan masyarakat modern. Pada masyarakat primitif, jika terjadi sebuah pelanggaran tabu diyakini akan mendatangkan sebuah hukuman atau sanksi dari alam gaib. Alam ghaib ini akan menghukum pelaggar dan masyarakat di sekitarnya. Dengan demikian, anggota masyarakat bisa menghindari pelanggaran terhadap tabu dan terhindar dari sanksi alam ghaib.

Di sisi lain, dalam masyarakat modern, tabu dalam pengertian larangan untuk tidak melakukan sesuatu, tetap dikenal. Hanya saja, berbeda dengan tabu dalam masyarakat primitif yang bersifat magis-religius dan pelanggarannya selalu dihubungkan dengan sanksi supernatural, tabu dalam masyarakat modern bersifat profan dan pelanggarannya hanya dihubungkan dengan rusaknya "tatanan" yang diidealkan. Karena itu, sanksi atau hukuman sosiallah yang akan diterima oleh pelanggar tabu dalam masyarakat modern. Sanksi atau hukuman sosial tersebut dapat berupa denda, hukuman penjara, atau pengasingan/pemboikotan.

Penelitian ini berupaya mendeskripsikan ungkapan tabu pada masyarakat Baduy di Provinsi Banten. Masyarakat Baduy merupakan suku asli Indonesia yang telah berabad-abad hidup di Desa Kanekes, Kecamatan Leuwidamar, Kabupaten Lebak, Banten, tanpa bantuan dari pihak luar. Masyarakat Baduy dikenal dengan kearifan lokalnya yang mengutamakan konservasi dengan gaya hidup terintegrasi dengan alam. Hingga saat ini sebagian masyarakat Baduy masih tetap mempertahankan adat dan budayanya dan belum terpengaruh arus modernisasi. Masyarakat Baduy merupakan penutur bahasa Sunda karena secara historis dan geografis, dulu Baduy merupakan wilayah Jawa Barat yang berbahasa Sunda.

Berbicara mengenai asal-usul masyarakat Baduy sampai hari ini masih menjadi perdebatan panjang. Ada ahli yang menyatakan bahwa masyarakat Baduy adalah masyarakat keturunan Padjadjaran yang menyingkir dari Utara ke Selatan, ada juga yang menyatakan bahwa masyarakat Baduy adalah penduduk asli yang telah berabad-abad tinggal di wilayah tersebut (Hakim, 2012). Masyarakat Baduy berasal dari Kerajaan Sunda-Padjadjaran yang tetap mempertahankan dengan gigih kejayaannya terhadap Islam yang mengalahkannya pada abad XVI.

Sementara itu, terkait dengan keyakinan yang dianut masyarakat Baduy, agama mereka disebut sunda wiwitan yang dianggap sebagai agama tertua di dunia. Masyarakat Baduy percaya kepada gusti nu maha suci, penguasa alam semesta yang mengutus Nabi Adam ke bumi mengatur kehidupan orang Baduy. Adapun Nabi Muhammad diutus untuk mengatur umat manusia di dunia di luar orang Baduy (Hakim, 2012).

Dari literatur yang lain, penamaan Badui, Baduy atau Urang Baduy (Orang Baduy) bagi seluruh penduduk Desa Kanekes merupakan sebutan yang telah digunakan sejak lama. Hal itu dapat ditelusuri dari laporan-laporan peneliti 
Belanda yang menyebut masyarakat yang tinggal di lereng Pegunungan Kendeng itu dengan sebutan Badoe'i, Badoei, Badoewi, Kanekes, dan Rawayan (Hakim, 2012). Diduga, sebutan-sebutan tersebut bukanlah sebutan yang berasal dari penduduk itu sendiri. Sebutan 'Baduy' diperkirakan telah digunakan oleh beberapa peneliti yang menyamakan masyarakat tersebut dengan kelompok masyarakat pengembara di Arab, Orang Badawi, sedangkan sebutan Kanekes atau Urang Kanekes, diduga merupakan sebutan yang berasal dari nama sungai, yaitu Ci Kanekes yang mengalir ke daerah tersebut (Garna, 1985). Masyarakat Desa Kanekes menamai dirinya sesuai dengan asal dan wilayah kampungnya, seperti Urang Cibeo untuk mereka yang tinggal di wilayah Kampung Cibeo, Urang Kaduketug, Urang Gajebo,Urang Tangtu (Baduy Dalam), dan Urang Panamping (Baduy Luar) juga kerap digunakan sebagai penanda akan identias mereka dalam cakupan wilayah berdasarkan adat.

Sebutan Baduy kini melekat pada penduduk Kanekes. Ketika kartu tanda penduduk (KTP) diperkenalkan untuk pertama kali pada tahun 1980 pada Masyarakat Adat Baduy, identitas sebagai Urang Baduy (Orang Baduy) dibubuhkan pada KTP mereka. Orang Baduy atau Baduy kini digunakan untuk menyebut individu atau masyarakatnya dan Kanekes merujuk pada nama wilayah atau desa mereka. Hal ini sebagaimana yang diungkapkan oleh Jaro Dainah, Kepala Desa Kanekes (2011) bahwa "Kanekes ngaran Desa, Baduy ngaran masyarakatna. Lian ti eta berarti sebutan nu diciptakeun ku urang luar Baduy" (Kanekes nama Desa, Baduy nama masyarakatnya. Selain dari itu, berarti sebutan yang diciptakan oleh orang luar Baduy).

Berbicara tentang konsep tabu, masyarakat Baduy menyebutnya dengan istilah pamali, sedangkan dalam bahasa Indonesia diselaraskan dengan kata larangan. Larangan dalam bahasa Sunda, khususnya di lingkungan masyarakat Banten diidentikkan dengan kata pamali/tabu (Satjadibrata, 2005). Kedua konsep itu merupakan dua konsep yang sama. Masyarakat Banten secara umum atau masyarakat Baduy secara khusus lebih banyak menggunakan istilah pamali untuk halhal yang dianggap tabu. Jadi, istilah pamali dan tabu merupakan satu konsep yang sama, yaitu yang dilarang, baik karena kekuatan yang membahayakan (tabu positif) maupun karena kekuatan yang mencemarkan atau merusak kekuatan hidup seseorang (tabu negatif).

Berkaitan dengan paparan di atas, ungkapan/kata pamali (Sunda) erat hubungannya dengan berbagai aspek kehidupan seperti budaya, keyakinan, dan kepercayaan yang bertolak dari tradisi dan kebiasaan yang berlaku dalam kehidupan masyarakat. Secara umum, ungkapan pamali juga berlaku di lingkungan masyarakat Baduy. Masyarakat Baduymemunyai pandangan yang berbeda terhadap suatu benda dan lingkungannya.

Dari paparan di atas, dapat dipahami bahwa sesuatu yang ditabukan atau pamali juga terdapat dalam bahasa dan budaya Baduy. Pamali tersebut hidup dan berkembang sampai sekarang. Berdasarkan gejala di atas, menarik untuk dikaji ihwal ungkapan larangan/pamali dalam bahasa masyarakat Baduy. Harapanya, hasil penelitian ini dapat menjadi salah satu upaya pemertahan- 
an bahasa dan budaya masyarakat Baduy yang hampir punah (Kemdikbud, 2011; Mardikantoro, 2016).

\section{METODE}

Penelitian ini dilaksanakan di masyarakat Baduy. Secara geografis, wilayah Baduy termasuk dalam wilayah Kecamatan Leuwidamar, Kabupaten Lebak, Provinsi Banten. Penelitian ini menggunakan pendekatan kualitatif dengan metode etnografi dan berancangan antropolinguistik (Emzir, 2010).

Data berupa ungkapan larangan yang dipatuhi oleh masyarakat Baduy. Sumber data yakni: 1) peristiwa, proses percakapan atau wawancara yang dilakukan dengan anggota masyarakat, jaro/puun, dan sumber yang lain, 2) informan, yaitu jaro/puun, anggota masyarakat Baduy, dan steakholder yang lain, 3) dokumen, informasi tertulis yang berkenaan dengan tabu dalam bahasa Sunda masyarakat Baduy. Teknik pengumpulan data yaitu: 1) observasi partisipan/pengamatan berperan serta, dengan cara terjun langsung dalam aktivitas kehidupan masyarakat Baduy; 2) wawancara, dilakukan dalam menggali data ungkapan larangan; 3) kajian dokumentasi dan pustaka, dilakukan dalam upaya mencari teori-teori pendukung penelitian ini; 4) membuat catatan lapangan, yaitu mencatat semua hal yang berlangsung pada saat penulis di lapangan, 5) membuat rekaman data, yaitu kegiatan mengklasifikasikan data penelitian. Analisis dilakukan selama pengumpulan, reduksi, penyajian, dan penarikan simpulan/verifikasi. Analisis data bersifat induktif-kualitatif.

\section{HASIL DAN PEMBAHASAN Hasil}

Temuan penelitian ungkapan larangan sebagai representasi tabu di lingkung-an masyarakat Baduy diklasifikasikan ke dalam tiga kategori, yaitu (1) ungkapan tabu yang berhubungan dengan aturan berladang (bertani); (2) ungkapan tabu yang berhubungan dengan aturan hidup bermasyarakat; dan (3) ungkapan tabu yang berhubungan dengan aturan pemanfaatan sumber daya hutan dan lingkungan. Temuan penelitian selengkapnya disajikan pada Tabel 1.

Data ungkapan tabu secara terperinci adalah: (a) sejumlah 25 ungkapan tabu yang berhubungan dengan aturan mengelola lahan pertanian, (b) sejumlah 34 ungkapan tabu yang berhubungan dengan aturan hidup bermasyarakat, dan sejumlah 11 ungkapan tabu yang berhubungan dengan pemanfaatan sumber daya hutan dan lingkungan. Data selengkapnya disajikan pada lampiran.

Tabel 1. Ungkapan Tabu pada Masyarakat Baduy

\begin{tabular}{cll}
\hline No. & Kategori & Subkategori \\
\hline 1. & Aturan dalam berladang & a. Persiapan berladang \\
& & b. Proses berladang \\
& c. Saat panen padi \\
2. Aturan hidup bermasyarakat & a. Bersifat pribadi \\
& & b. Bersifat kolektif (umum) \\
3. Aturan pemanfaatan sumber daya hutan & a. Penghormatan pada hutan \\
& dan lingkungan & b. Pengolahan tanah (lingkungan) \\
\hline
\end{tabular}


Seperti telah dijelaskan pada bagian pendahuluan, ungkapan larangan erat hubungannya dengan berbagai aspek kehidupan seperti budaya, keyakinan, dan kepercayaan yang bertolak dari tradisi dan kebiasaan yang berlaku dalam kehidupan masyarakat. Masyarakat Baduy mempunyai pandangan yang berbeda terhadap suatu benda dan lingkungannya. Bertolak dari pandangan itu, masyarakat Baduy memunyai cara untuk menghindari hal-hal yang terncantum dalam ungkapan larangan tersebut. Salah satu ungkapan larangan dalam masyarakat Baduy, yaitu lojor teu menang dipotong, pondok teu meunang disambung (panjang tidak boleh dipotong, pendek tidak boleh disambung). Ungkapan tersebut memberikan pemahaman bahwa seluruh anggota masyarakat Baduy harus hidup apa adanya, kalau berlebihan tidak boleh sombong, kalau kurang harus menerima apa adanya.

\section{Pembahasan}

\section{Ungkapan Tabu Berkaitan dengan Kegiatan Berladang}

Ungkapan tabu yang menjadi pantangan dalam kegiatan berladang atau bertani merujuk pada pikukuh "gunung teu meunang dilebur, lebak teu meunang dirusak". Pikukuh tersebut menjadi acuan masyarakat Baduy pada saat berladang. Berdasarkan temuan penelitian, ungkapan tabu dalam berladang dapat dikelompokkan dalam tiga kegiatan: a) pada saat mulai berladang, b) pada masa berladang, dan c) pada masa panen. Secara lengkap pembahasan temuan penelitian berkait dengan kegiatan pada saat memulai berladang, proses berladang, dan pada saat panen, dipaparkan di bawah ini.
Pertama, ungkapan tabu pada saat memulai berladang. Terdapat beberapa ungkapan larangan yang tidak boleh dilakukan oleh masyarakat Baduy pada saat memulai berladang, antara lain: tong ngabulak-balik taneuh (jangan membolak-balikan tanah); ngebon kudu nurut ka puun (berkebun harus mematuhi puun); ngebon kudu babarengan (berkebun harus sama-sama); dan taneuh tong dirusak (tanah jangan dirusak).

Pada saat memulaimembuatladang, masyarakat Baduy tidak menggunakan cangkul. Tanah yang digunakan untuk menanam tidak dicangkul dan dibolakbalik, tetapi hanya membuat lubang di tanah tersebut. Untuk menanam padi, mereka hanya menggunakan tugal, yaitu sejenis batang pohon yang dibuat runcing di ujungnya untuk membuat lubang di tanah yang digunakan untuk menanam padi.

Masyarakat Baduy pada saat berladang sama sekali tidak mengubah bentuk tanah ladang. Mereka tidak berani merusak bentuk asli tanah karena mereka percaya tanah adalah titipan dari para leluhur mereka dan harus tetap dijaga. Ungkapan larangan/pamali tersebut dipercaya ketika tidak mengubah bentuk tanah akan terhindar dari bencana alam seperti banjir ataupun longsor.

Mereka tidak saling mendahului dalam berladang. Selain itu, tempat berladang pun harus berdasarkan aturan atau ketentuan puun dan sama sekali tidak dibolehkan membuka ladang di leuweung titipan serta tidak diperbolehkan membuat sawah dan kolam ikan.

Ungkapan larangan ini selaras dengan prinsip masyarakat Baduy yang senantiasa menjaga keselarasan dengan alam. Dalam kehidupan sehari-hari, 
masyarakat Baduy memunyai pikukuh (tradisi) yang mengatur gaya hidup masyarakat Baduy sehingga proses kehidupan berjalan alami yang didukung oleh kontinuitas konservasi margasatwa dan habitat tumbuhan (Garna, 1985).

Kedua, ungkapan tabu pada saat proses berladang. Sebelum membahas ungkapan larangan pada saat proses berladang, terlebih dahulu dipaparkan jenis-jenis ladang (huma) di lingkungan masyarakat Baduy, yaitu (1) huma serang, tempatnya di taneuh larangan pemiliknya girang seurat; (2) huma puun, tempatnya di taneuh larangan pemiliknya puun; (3) huma tangtu, tempatnya di taneuh larangan milik warga tangtu; (4) huma tuladan, lokasinya di pajaroan milik para jaro dan kokolot; (5) huma panamping, lokasinya di daerah panamping, milik warga panamping; dan (6) huma urang Baduy, luar Desa Kanekes, milik warga Pajaroan (Hakim, 2012).

Terdapat beberapa ungkapan larangan yang tidak boleh dilakukan oleh masyarakat Baduy pada saat proses berladang, antara lain: mun gawe dihuma serang (puun) kudu tartib (kalau berladang di lahan puun, haruslah tertib); mun gawe dihuma serang (puun) kudu tartib (kalau berladang di lahan puun, haruslah tertib); teu meunang ngaroko mun keur gawe di huma serang (tidak boleh merokok kalau sedang bekerja di lahan (ladang); ulah nyiduh mun keur gawe di huma serang (jangan meludah kalau sedang bekerja di lahan (ladang)'; teu meunang ngomong nyadok mun gawe di huma serang (jangan berbicara kotor atau kasar kalau sedang bekerja di lahan (ladang)'; kudu make baju bersih lamun gawe di huma serang (harus menggunakan baju bersih kalau sedang bekerja di lahan (ladang)'; dan lamun gawe di huma serang, lalaki kudu make iket (kalau bekerja di lahan (ladang), lelaki harus mengenakan iket')

Terkait dengan ungkapan larangan yang merepresentasikan tabu pada saat proses berladang, terdapat beberapa hal yang menjadi pantangan yang dianut masyarakat Baduy, terutama yang berkaitan dengan huma serang yang berada ditaneuhlarangan. Secara umum ungkapan larang/pamali pada saat proses berladang/ngahuma di masyarakat Baduy hampir sama seperti tidak mengubah bentuk tanah, tidak boleh menggunakan pupuk dan obat kimia, serta tidak menanam budidaya perkebunan. Ungkapan larangan yang lebih kental dan tidak boleh dilanggar oleh masyarakat Baduy, yaitu pada saat bekerja di huma serang milik girang seurat, aturan tersebut antara lain selama bekerja di huma serang tidak boleh mengotori lahan (berak), tidak boleh merokok, tidak boleh meludah, tidak boleh kentut, dan tidak boleh berbicara kotor/kasar. Selain itu, seluruh masyarakat Baduy pada saat bekerja di huma serang harus memakai pakaian bersih dan bagi kaum pria atau laki-laki harus memakai ikat.

Ketiga, ungkapan tabu pada saat panen padi di ladang. Ungkapan larangan yang tidak boleh dilakukan oleh masyarakat Baduy pada saat panen, antara lain: pare teu meunang dibawa kana motor (padi tidak boleh diangkut dengan motor); pare teu meunang digiling, kudu ditutu (padi tidak boleh digiling, tetapi harus ditumbuk); pare teu meunang dihuru (padi tidak boleh dibakar atau dibuat kerak); pare teu meunang dipiceun (padi tidak boleh dibuang atau disia-siakan)'; ulah ngajual pare (tidak boleh menjual padi); dan teu meunang maling pare (tidak boleh mencuri padi). 
Setelah masa membuat ladang dan masa berladang, masa selanjutnya adalah masa panen. Pada saat masa panen pun banyak aturan yang tidak boleh dilanggar oleh seluruh masyarakat Baduy, antara lain hasil panen atau padi tidak boleh dibawa naik kendaraan, baik motor maupun mobil, padi tidak boleh digiling di penggilingan padi, tetapi harus ditumbuk di lumbung yang sudah disiapkan di perkampungan. Selain itu, hasil panen tidak boleh diperjualbelikan dan dibuang percuma. Bahkan, aturan yang paling ketat, yaitu masyarakat Baduy tidak boleh mencuri padi. Jika aturan-aturan tersebut dilanggar, pelanggar akan mendapatkan sanksi secara pribadi bahkan mungkin akan mendapatkan bencana secara keseluruhan.

\section{Ungkapan Tabu dalam Aturan Hidup Bermasyarakat}

Dalam beberapa literatur yang berkembang di masyarakat, secara umum masyarakat Baduy digambarkan sebagai masyarakat terbelakang dibandingkan masyarakat Indonesia atau Banten secara umum. Hal ini disebabkan masyarakat Baduy menolak/tidak menerima perkembangan zaman atau modernisme. Hal ini terlihat dari aktivitas kehidupan sehari-hari yang tidak mengenal perkembangan elektronik, seperti tidak memiliki televisi, radio, telepon genggam, bahkan alat penerangan pun mereka tidak memakai listrik. Sementara itu, untuk meningkatkan kemampuan dalam pemahaman atau peningkatan pengetahuan pun, mereka tidak membolehkan masyarakatnya untuk bersekolah seperti anakanak di masyarakat Lebak secara umum (Garna, 1985; Hakim, 2012).
Sementara itu, karena kesederhanaan hidup yang dianut masyarakat Baduy, para ahli menggambarkan bahwa masyarakat Baduy adalah masyarakat miskin. Berdasarkan hasil observasi selama pengambilan data, untuk memenuhi kebutuhan sandang, pangan, dan papan mereka sama sekali tidak berlebihan karena mereka memegang filosofi kesederhanaan hidup. Misalnya, jangan pernah berharap mereka memiliki atau punya televisi atau alat elektronik lainnya, begitupun dengan alatalat rumah tangga lain, seperti piring dan gelas.

Berdasarkan hasil wawancara dengan salah seorang narasumber, masyarakat Baduy hidup apa adanya dan tidak berlebihan. Mereka secara umum sangat memegang prinsip kearifan dalam kehidupan sehari-harinya. Prinsip kearifan yang dipatuhi secara turun-temurun ini membuat mereka tampil sebagai sebuah masyarakat yang mandiri, baik secara sosial maupun secara ekonomi.Orang Baduy tidak saja mandiri dalam memenuhi kebutuhan sandang, pangan, dan papan, tetapi juga dalam kehidupan sehari-hari mereka tidak membeli beras karena menanam sendiri. Mereka tidak membeli baju, tetapi menenun kain sendiri.Kayu sebagai bahan pembuat rumah pun mereka tebang di hutan mereka, yang keutuhan dan kelestariannya tetap terjaga. Dari 5.136,8 hektar kawasan hutan di Baduy, sekitar 3.000 hektar hutan dipertahankan untuk menjaga 120 titik mata air.

Kemandirian masyarakat Baduy juga tampak pada beberapa hal lainnya. Misalnya, untuk penerangan, mereka tak menggunakan listrik. Dalam bercocok tanam, mereka tidak menggunakan pupuk buatan pabrik. Mereka 
juga membangun dan memenuhi sendiri kebutuhan untuk pembangunan infrastruktur, seperti jalan desa, lumbung padi, dan sebagainya.

Berdasarkan temuan penelitian, ungkapan larangan sebagai representasi tabu yang berhubungan dengan aturan hidup bermasyarakat diklasifikasl dalam dua sifat, yaitu: a) aturan hidup yang bersifat pribadi, dan b) aturan hidup yang bersifat umum. Terkait dengan paparan mengenai ungkapan $p a-$ mali dalam aturan hidup bermasyarakat di lingkungan masyarakat Baduy, berdasarkan hasil temuan ditemukan sebanyak 34 ungkapan pamali yang merepresentasikan tabu. Secara umum, ungkapan tabu tersebut dijadikan sebagai pedoman hidup oleh seluruh masyarakat Baduy, baik tabuyang bersifat individu, maupun tabu yang bersifat umum atau menyeluruh.

Pertama, ungkapan tabu berkaitan dengan aturan hidup yang bersifat pribadi. Ungkapan larangan yang dengan aturan hidup yang bersifat pribadi, antara lain: Teu meunang bohong (tidak boleh bohong); Lamun meuli ulah nawar (kalau membeli atau berbelanja, jangan menawar); teu meunang make sendal (tidak boleh memakai sandal); teu meunang boga tivi (tidak boleh memiliki televisi); ulah barang dahar lamun geus sore (jangan makan (nasi atau kudapan lain) jika sudah sore); teu meunang make anu sesengitan (tidak boleh memakai wewangian); ulah make sabun mun keur mandi (jangan menggunakan sabun mandi); ulah make odol lamun nyikat gigi (jangan menggunakan pasta gigi); dan ulah sok nabeng-nabeng gambar di imah (jangan suka memasang/menempel gambargambar di rumah).
Kedua, ungkapan tabu berkaitan dengan aturan hidup yang bersifat umum. Ungkapan larangan yang berkaitan dengan aturan hidup yang bersifat umum, antara lain: ulah make lampu pamarentah (jangan menggunakan listrik (dari pemerintah)'; ulah make jalan hideung (jangan menggunakan jalan aspal); ulah sakola pamarentah (jangan bersekolah); lamun gering ulah ka mantri (kalau sakit, jangan berobat ke petugas kesehatan (mantri)'; teu meunang naek motor/mobil (tidak boleh naik motor/mobil); nyieun imah ulah make paku (membuat rumah jangan menggunakan paku); dan ulah sok pindah agama (jangan berpindah agama (keyakinan).

Berdasarkan paparan di atas, sangatlah wajar adanya anggapan bahwa masyarakat Baduy adalah masyarakat miskin karena pada umumnya parameter kesejahteraan diukur berdasarkan hal-hal yang bersifat materi (kekayaan), seperti memiliki kendaraan, memakai perhiasaan, memiliki tanah yang luas, dan memiliki rumah mewah. Sementara itu, kenyataan yang tergambar dalam keseharian, baik secara individu maupun secara umum, masyarakat Baduy tidak memakai perhiasan, tidak memakai wangi-wangian, tidak memiliki rumah mewah, dan tidak memiliki kendaraan, serta alat elektronik. Kenyataan tersebut bukan karena masyarakat Baduy tidak memiliki keinginan seperti halnya masyarakat umum, tetapi karena mereka memegang teguh aturan hidup yang sudah turun-temurun diajarkan oleh para pendahulunya dan sangat takut dengan akibat yang ditimbulkan ketika mereka melanggar aturan tersebut. Mereka patuh untuk tidak melanggar larangan dan patuh pada perintah atau keharus- 
an adat. Hal itu terlestarikan dalam ungkapan larangan pamali yang merepresentasikan tabu dan masih mereka yakini hingga saat ini.

\section{Ungkapan Tabu dalam Aturan Peman- faatan Sumber Daya Hutan dan Ling- kungan}

Masyarakat Baduy pada dasarnya sama dengan masyarakat atau suku bangsa lain di dunia. Mereka memiliki ciri-ciri khas yang membedakan dengan suku bangsa lain. Masyarakat Baduy termasuk ke dalam lingkungan hukum adat Jawa Barat (sekarang masuk wilayah Provinsi Banten) bersamasama dengan kelompok orang Betawi, orang Banten, dan orang Sunda.

Berdasarkan data yang diambil dari pemerintah kabupaten Lebak, luas wilayah administratif permukiman masyarakat Baduy di Desa Kanekes, Kecamatan Leuwidamar, yaitu 5.101, 85 ha, terdiri atas kawasan hutan lindung 2.946 ha dan hutan produksi 2.155 ha. Sementara itu, lokasi tempat tinggal masyarakat Baduy berada di pegunungan Kendeng, Banten Selatan. Kawasan Gunung Kendeng dikenal sebagai sumber beberapa mata air sungai yang mengalir ke segala penjuru mata angin sehingga mereka biasa disebut sebagai pengawas daerah konservasi alam di Banten (Hakim, 2012).

Berdasarkan hal di atas, dapat dipahami bahwa masyarakat Baduy memiliki wilayah yang jelas berdasarkan peraturan daerah Kabupaten Lebak dan memiliki sistem pemerintahan ganda, yaitu aturan hidup yang didasarkan pada aturan puun (pemerintahan adat) dan aturan yang mengacu kepada peraturan pemerintah kabupaten. Kedua sistem itu dijalankan secara simultan dan terus-menerus dari para pendahulunya hingga saat ini. Kepala pemerintahan adat berkedudukan di Kejeroan atau Tangtu Tilu (Kampung Cibeo, Cikertawana, dan Cikeusik), yang dipimpin oleh seorang puun. Seluruh masyarakat Baduy dalam segala macam aktivitasnya, baik yang bersifat sosial, agama, maupun adat istiadat harus tunduk pada aturan yang dikeluarkan puun. Sementara itu, untuk menghubungkan kepentingan dan komunikasi antara masyarakat Baduy dan pemerintah Kabupaten Lebak, biasanya dipimpin oleh seorang jaro pamarentah yang berkedudukan di kampung Kaduketug. Tugas jaro pamarentah adalah menyampaikan hal-hal yang berkaitan dengan kepentingan seluruh masyarakat Baduy ke pemerintah Kabupaten Lebak dalam hal ini bupati dan juga turut serta dalam program yang dilaksanakan oleh pemerintah Kabupaten Lebak.

Berdasarkan catatan yang ada, lahan permukiman masyarakat Baduy yang terdiri atas pegunungan dengan lembah yang curam merupakan tanah hak ulayat yang diakui batas-batasnya oleh pemerintah sejak tahun 1986. Menurut pengakuan masyarakat Baduy, tanah yang mereka tinggali adalah taneuh titipan karuhun yang harus mereka pelihara dengan baik dan dijaga dari pengaruh modernisme atau perkembangan kemajuan zaman.

Untuk menjaga taneuh titipan dari pengaruh kemajuan zaman dan modernisme, banyak aturan yang mengikat yang tidak boleh dilakukan oleh seluruh anggota masyarakat Baduy. Aturanaturan tersebut biasanya disampaikan dalam tuturan lisan dari para pendahulunya. Akan tetapi, aturan-aturan 
tersebut sangat dipatuhi dalam semua aktivitas kehidupan masyarakat Baduy.

Salah satu aturan yang masih dipegang kuat oleh masyarakat Baduy, yaitu aturan pemanfaatan sumber daya hutan dan lingkungan yang diungkapkan ke dalam bentuk ungkapan larangan yang merepresentasikan tabu. Ungkapan tersebut dibagi ke dalam dua bagian, yakni (a) ungkapan tabu yang berkaitan dengan taneuh titipan (tanah titipan), dan (b) ungkapan tabu yang berkaitan dengan hutan dan lingkungan.

Pertama, ungkapan larangan yang berkaitan dengan taneuh titipan (tanah titipan). Ungkapan larangan berkaitan dengan taneuh titipan (tanah titipan), antara lain: teu meunang ngahuma di taneuh titipan (tidak boleh berladang di lahan titipan); dan teu meunang mawa jelema jangkung $k a$ taneuh titipan (tidak boleh membawa orang yang tinggi (Cina atau bule) ke tanah titipan).

Masyarakat Baduy sangat kuat memegang pikukuh atau aturan hidup yang berlaku dalam aktivitas kehidupan sehari-harinya. Begitupun dalam kegiatan pemanfaatan sumber daya hutan dan lingkungan. Terdapat beberapa aturan atau ungkapan larangan/pamali sebagai representasi tabu yang harus dipatuhi oleh seluruh anggota masyarakat Baduy. Misalnya, anggota masyarakat Baduy tidak boleh membuka ladang di leuweung titipan/leuweung lindungan lembur.

Berdasarkan aturan itu, tidak ada satu pun anggota masyarakat Baduy yang berani membuka ladang di tanah titipan tersebut kecuali puun. Begitupun dengan aturan yang kedua, yakni seluruh anggota masyarakat Baduy dilarang menebang pohon/kayu di tanah/leuweung titipan. Tidak ada satu pun dari anggota masyarakat Baduy yang berani melanggar aturan tersebut karena ketika mereka melanggar akan mendapatkan sanksi dari puun. Bahkan, pelanggaran tersebut dapat berdampak pada masayarakat Baduy secara umum, misalnya datangnya musibah atau penyakit yang mendera masyarakat.

Selanjutnya aturan lain yang berkait dengan taneuh/leuweung titipan adalah anggota masyarakat Baduy tidak boleh memasuki taneuh/leuweung titipan, apalagi bagi warga luar Baduy. Mereka sangat dilarang memasuki taneuh, titipan terutama warga yang berkulit putih seperti Cina dan Bule. Aturan terakhir, yaitu tidak boleh memotret taneuh/leuweung titipan karena akan mengakibatkan bencana alam dan akan mendapatkan sanksi dari puun.

Berdasarkan hasil wawancara dengan anggota masyarakat Baduy, ketika ditanya langsung tentang aturanaturan tersebut, sebagian besar tidak dapat menjelaskan alasan secara logis. Mereka hanya mengatakan bahwa itu sudah menjadi aturan/larangan yang harus dipatuhi sejak dahulu, yang mereka katakan dalam bahasa Sunda "eta mah geus tidituna atau teu wasa" (Satjadibrata, 2005).

Kedua, ungkapan larangan yang berkaitan dengan pemanfaatan sumber daya hutan dan lingkungan. Ungkapan larangan berkaitan dengan pemanfaatan sumber daya hutan dan lingkungan, antara lain: ulah nuar kayu di leuweung titipan (jangan menebang kayu di hutan titipan); ulah nyieun jalan cai (jangan membuat jalan air (irigasi, bendungan); taneuh ulah dijeun undak-undakan (tanah jangan dibuat terasering/sengkedan); taneuh ulah dijeun undak-undakan (tanah jangan dibuat terasering/sengkedan); 
dan ulah ngebon cengkeh jeung kopi (jangan berkebun cengkih dan kopi).

Berdasarkan larangan tersebut, mereka percaya bahwa mengubah jalur air akan mengakibatkan banjir melanda masyarakat Baduy. Berdasarkan aturan tersebut, mereka membiarkan aliran air apa adanya dan tidak pernah membuat irigasi atau membuat bendungan untuk keperluan pemenuhan air dalam kehidupannya. Masyarakat Baduy sangat percaya ketika mereka membuat irigasi sama saja dengan meungpeuk rejeki ti pangeran padahal mereka menganggap bahwa air adalah sumber kehidupannya.

Kepatuhan masyarakat Baduy pada larangan ini terlihat dari bentuk ladang yang yang berdasarkan kontur tanah. Mereka percaya ketika mengubah bentuk tanah akan mengakibtkan bencana longsor atau gempa. Oleh sebab itu, dalam aplikasi kehidupan bertanam/ berladang, biasanya mereka mengikuti bentuk tanah apa adanya. Selain itu, dalam pemahaman mereka mengubah bentuk tanah sama saja dengan ngaruksak ciptaan pangeran. Oleh karena itu, mereka meyakini bahwa tanah harus dijaga agar tidak rusak dan dampak pengaruh kemajuan zaman.

Dari aturan larangan tersebut, mereka percaya bahwa sengkedan atau terasering merupakan perwajahan status sosial. Dalam aturan hidup masyarakat Baduy, mereka menganggap bahwa semua masyarakat Baduy memiliki kedudukan yang sama, tidak ada kaya atau miskin, semuanya harus sama di hadapan pangeran, puun, dan kepercayaannya.

Aturan tersebut memberikan pemahaman bahwa secara status sosial masyarakat Baduy tidak memiliki apa- apa. Jika tanah dimiliki, akan terjadi silang sengketa terkait dengan kepemilikan tanah. Selain itu,akan melahirkan kedudukan/ status sosial yang berbedabeda.Pada akhirnya, hal ituakan menjadi pemicu ketidakharmonisan dalam kehidupan bermasyarakat bahkan yang lebih parah lagi akan terjadi perebutan tanah antarseluruh masyarakat Baduy.

Aturan penanaman pohon di ladang pun menjadi hal yang menarik untuk dianalisis. Dalam aturan tersebut, masyarakat Baduy tidak diperbolehkan menanam tanaman yang bersifat ekonomis seperti cengkeh dan kopi.

Berdasarkan hal tersebut, jika dianalisis secara logika, dapat disimpulkan bahwa ketika masyarakat Baduy dibiarkan menanam pohon yang bersifat ekonomis akan mengakibatkan kecemburuan sosial atau akan terjadi persaingan di dalam anggota masyarakat Baduy tersebut. Hal itu tentunya berdampak pada terjadinya perbedaan status sosial sehingga akan memicu persaingan sosial di kalangan masyarakat Baduy itu sendiri.

Ditinjau dari aspek linguistik, bentuk formal ungkapan larangan dapat dikategorikan sebagai tuturan imperatif berjenis larangan dan perintah. Imperatif larangan diindikasikan oleh digunakannya kata ulah, tong, dan teu meunang. Kata-kata itu digunakan di depan verba sehingga mengeksplisitkan larangan (pantangan atau ketidakbolehan dilanggar). Contohnya: ulah barang dahar lamun geus sore, pepelakan tong make pupuk, dan bisi taneuh rusakteumeunang ngahuma di taneuh titipan. Katakata tersebut digunakan sebagai penanda lingual yang menyatakan larangan keras. Adapun imperatif perintah diindikasikan oleh digunakannya kata 
kudu, lamun/mun yang secara semantik menunjukkan keharusan (tidak boleh tidak, mesti dilakukan). Contohnya: ngebon kudu babarengan, lamun gawe di huma serang, lalaki kudu make iket, danmun gawe dihuma serang (puun) kudu tartib. Dalam perspektif lebih luas, ungkapan larangan pada masyarakat Baduy juga merupakan salah bentuk ekspresi kebahasaan sebagai bagian integral dari budaya masyarakat (Pilotti, 2012).

\section{SIMPULAN}

Berdasarkan temuan dan pembahasan penelitian berkait dengan ungkapan larangan sebagai repesentasi tabu di lingkungan masyarakat Baduy, disimpulkan dua hal berikut ini. Pertama, secara umum, ungkapan larangan sebagai representasi tabu yang berlaku di lingkungan masyarakat Baduy terbagi ke dalam tiga kategori, yaitu (a) ungkapan tabu yang berkaitan dengan kegiatan berladang (betani); (b) ungkapan tabu yang berkaitan dengan aturan hidup bermasyarakat, dan (c) ungkapan tabu yang berkaitan dengan aturan dalam pemanfaatan sumber daya hutan dan lingkungan. Masingmasing aturan tersebut memiliki sub/ bagian-bagian tersendiri. Berdasarkan temuan hasil penelitian, ungkapan tabu yang berkaitan dengan pengelolaan lahan pertanian terformulasikan ke dalam 25 ungkapan larangan yang harus dipatuhi dan dijalankan oleh seluruh masyarakat Baduy, baik berupa larangan maupun perintah dengan penanda lingual masing-masing, yakni kata-kata yang mengindikasikan larangan dan kata-kata yang mengindikasikan perintah. Ungkapan pamali yang berkaitan dengan aturan hidup bermasyarakat terformulasikan ke dalam 34 ungkap- an pamali, baik berupa larangan maupun perintah dengan penanda lingual masing-masing, yakni kata-kata yang mengindikasikan larangan dan katakata yang mengindikasikan perintah. Adapun ungkapan pamali yang berkaitan dengan pemanfaatan sumber daya hutan dan lingkungan terformulasikan ke dalam 11 ungkapan pamali berupa larangan dengan penanda lingual berupa kata-kata yang mengindikasikan larangan. Temuan-temuan ungkapan pamali tersebut penulis peroleh pada saat berdiskusi/ngobrol dengan sumber data ketika penulis berinteraksi langsung di rumah atau di lingkungan permukiman masyarakat Baduy.

Kedua, ungkapan larangan sebagai representasi tabu yang berlaku dan dilaksanakan secara aktif oleh masyarakat Baduy merupakan aturan hidup yang diwariskan oleh nenek moyang mereka secara turun-temurun melalui bahasa lisan. Ungkapan tersebut secara linguistik terformulasikan ke dalam bentuk pernyataan imperatif, baik larangan maupun perintah. Ungkapan tersebut tidak terdokumentasikan seperti halnya Alquran, kitab, atau ajaran-ajaran lain yang dibukukan. Masyarakat Baduy hanya memperoleh secara lisan yang disampaikan oleh para pendahulunya. Namun, walau hanya berupa ajaran/aturan lisan, seluruh anggota masyarakat Baduy melaksanakan dengan baik dan sungguh-sungguh. Bahkan, mereka sangat takut untuk melanggar aturan tersebut.

\section{UCAPAN TERIMA KASIH}

Ucapan terima kasih disampaikan kepada Universitas Sultan Ageng Tirtayasa yang telah memfasilitasi penda- 
naan penelitian melalui Lembaga Penelitian dan Pengaabdian Masyarakat. Ucapan terima kasih disampaikan pula kepada narasumber (pu'un) masyarakat Baduy yang telah membantu proses pengumpulan data dan kepada teman sejawat yang membantu validasi dan verifikasi data dan temuan penelian.

\section{DAFTAR PUSTAKA}

Bakhtiar, M. (2011). Assesing The Offensiveness Level of Tabo Words in Persian. The Journal of Internasional Social Research. 4 (19), 15-23. Retrieved from http://www.sosyalarastirmalar.com/cilt4/sayi19_pdf/1_ dil_edebiyat/bahtiar_mohsen.pdf.

Burridge, K. \& Allan, K. (2006). Forbidden Words. New York: Cambridge University Press.

Chaer, A. (2009). Sosilinguitik. Jakarta: Rineka Cipta.

Emzir. (2010). Metode Penelitian Kualitatif Analisis Data. Jakarta: Rajawali Press.

Fallo, JD \& Rokhman, F. (2016). Tuturan Ritual Natoni Adat Masyarakat Etnis Timor dalam penyambutan Tamu di Sekolah. Seloka: Jurnal Pendidikan Bahasa dan Sastra Indonesia. 5 (2),105-114. Retrieved from https:// journal.unnes.ac.id/sju/index. php/seloka/article/view/13070.

Frazer, Sir JG. (1980). Taboo and The Perils Of The Soul. Hongkong: The Macmillan Press Ltd.

Freud, S. (1950). Totem and Taboo. Charleston : Bibliolife

Garna, Y K. (1985). Orang Baduy. Jakarta: Departemen Pendidikan dan Kebudayaan.

Gay, M. \& Susanti, PA. (2017). Taboo Language Within Ternate Society: A Study on Its Formation and Reference. Journal of Intensive Studies on Language, Arts, and Culture. 1 (1), 170-183. Retrieved from DOI: http://dx.doi.org/10.17977/ um006v1i12017p170.

Hakim, L. (2012). Baduy dalam Selubung Rahasia. Banten: Biro Humas dan Protokol Setda Banten.

Hinnels, J.R. (1984). The Dictionary of Religious. London: Penhuin Books

Humaeni, A. (2015). Mitos dan Taboo dalam Budaya Masyarakat Banten. Banten: LP2M IAIN Sultan Maulana Hasanudin Banten.

Humaeni, A. (2015). Tabu Perempuan dalam Budaya Masyarakat Banten. Jurnal Humaniora. 27 (2), 174-185. DOI: https://doi.org/10.22146/ jh.v27i2.10585

Kemendikbud. (2011). Pemberdayaan Bahasa Indonesia Memperkukuh Budaya Bangsa dalam Era Globalisasi. Jakarta: Badan Pengembangan dan Pembinaan Bahasa Kemendikbud.

Koentjaraningrat. (2009). Ilmu Antropologi. Jakarta: Rineka Cipta.

Kridalaksana, H. (2007). "Bahasa dan Linguistik" dalam Pesona Bahasa. Edit oleh Kushartanti. Jakarta: Gramedia.

Mardikantoro, H.B. (2016). Pemertahanan Bahasa Jawa dalam Pertunjukan Kesenian Tradisional di Jawa Tengah. Litera: Jurnal Penelitian Bahasa, Sastra, dan Pengajarannya. 15 (2), 269-280.DOI: https://doi. org/10.21831/1tr.v15i2.11828

Mondolalo, D. (2015). Kajian Hermeneutik Nilai-Nilai Kearfian Lokal Kata-kata Falia (Tabu) Masyarakat Muna. Jurnal Riksa Bahasa, 1 (2), 170-176.

Pilotii, M. (2012). Taboo Words in Expresive Language: Do Sex and 
Primary Language Matter. American International Journal of Contemporary Reseacrh. 2 (2).17-16. Retrieved from http://www.aijcrnet.com/journals/Vo1_2_No_2_ February_2012/3.pdf.

Rodman, R. (1988). An Introduction to Language USA: The Dryden Press.

Satjadibrata, R. (2005). Kamus Basa Sunda. Bandung: Kiblat.

Smith, F. A. (2007). The Taboos Of Leadership. San Francisco: Wiley.
Sumarsono. (2012). Sosiolinguistik. Yogyakarta: Pustaka Pelajar.

Webster, H. (1942). Taboo. A Sociology Study. California: Stanford University Press.

Zare, D. \& Tayyebi, G. (2014). Iranian EFL Learners' Perception of English Taboo Words: A Case of Gender Differences. Spectrum: A Juornal of Multidisciplinary Research. 3 (12), 7-13. 


\section{Lampiran: Data Penelitian Ungkapan Larangan}

Tabel 1. Ungkapan Tabu dalam Mengelola Lahan Pertanian

\begin{tabular}{|c|c|c|}
\hline No & Ekspresi Ungkapan Tabu & Bentuk Formal \\
\hline 1. & $\begin{array}{l}\text { Tong ngabulak-balik taneuh } \\
\text { 'Jangan membolak-balikan tanah' }\end{array}$ & $\begin{array}{l}\text { Imperatif } \\
\text { Larangan }\end{array}$ \\
\hline 2. & $\begin{array}{l}\text { Pepelakan tong make pupuk, bisi taneuh rusak } \\
\text { 'Tanaman jangan memakai pupuk, khawatir tanah rusak' }\end{array}$ & $\begin{array}{l}\text { Imperatif } \\
\text { Larangan }\end{array}$ \\
\hline 3. & $\begin{array}{l}\text { Ngebon kudu nurut ka puun } \\
\text { 'Berkebun harus mematuhi puun' }\end{array}$ & $\begin{array}{l}\text { Imperatif } \\
\text { Perintah }\end{array}$ \\
\hline 4. & $\begin{array}{l}\text { Ngebon kudu babarengan } \\
\text { 'Berkebun harus sama-sama' }\end{array}$ & $\begin{array}{l}\text { Imperatif } \\
\text { Perintah }\end{array}$ \\
\hline 5. & $\begin{array}{l}\text { Taneuh tong dirusak } \\
\text { 'Tanah jangan dirusak' }\end{array}$ & $\begin{array}{l}\text { Imperatif } \\
\text { Larangan }\end{array}$ \\
\hline 6. & $\begin{array}{l}\text { Ngebon ulah make pacul jeung kored, kudu ku aseuk } \\
\text { 'Berkebun jangan menggunakan pacul, tetapi harus dengan aseuk' }\end{array}$ & $\begin{array}{l}\text { Imperatif } \\
\text { Larangan }\end{array}$ \\
\hline 7. & $\begin{array}{l}\text { Ulah nyieun tanueh undak-undakan } \\
\text { 'Jangan membuat terasering/sengkedan' }\end{array}$ & $\begin{array}{l}\text { Imperatif } \\
\text { Larangan }\end{array}$ \\
\hline 8. & $\begin{array}{l}\text { Ulah melak jagong jeung kacang } \\
\text { 'Jangan menanam jagung dengan kacang' }\end{array}$ & $\begin{array}{l}\text { Imperatif } \\
\text { Larangan }\end{array}$ \\
\hline 9. & $\begin{array}{l}\text { Teu meunang ngebon sakadaek } \\
\text { 'Jangan berkebun semau-maunya' }\end{array}$ & $\begin{array}{l}\text { Imperatif } \\
\text { Larangan }\end{array}$ \\
\hline 10. & $\begin{array}{l}\text { Teu meunang muka taneuh titipan } \\
\text { 'Jangan membuka ladang di lahan titipan' }\end{array}$ & $\begin{array}{l}\text { Imperatif } \\
\text { Larangan }\end{array}$ \\
\hline 11. & $\begin{array}{l}\text { Mun gawe dihuma serang (puun) kudu tartib } \\
\text { 'Kalau berladang di lahan puun, haruslah tertib' }\end{array}$ & $\begin{array}{l}\text { Deklaratif } \\
\text { Pengandaian }\end{array}$ \\
\hline 12. & $\begin{array}{l}\text { Teu meunang ngising di huma serang } \\
\text { 'Tidak boleh buang air besar di lahan (ladang)' }\end{array}$ & $\begin{array}{l}\text { Imperatif } \\
\text { Larangan }\end{array}$ \\
\hline 13. & $\begin{array}{l}\text { Teu meunang ngaroko mun keur gawe di huma serang } \\
\text { 'Tidak boleh merokok kalau sedang bekerja di lahan (ladang)' }\end{array}$ & $\begin{array}{l}\text { Imperatif } \\
\text { Larangan }\end{array}$ \\
\hline 14. & $\begin{array}{l}\text { Ulah nyiduh mun keur gawe di huma serang } \\
\text { 'Jangan meludah kalau sedang bekerja di lahan (ladang)' }\end{array}$ & $\begin{array}{l}\text { Imperatif } \\
\text { Perintah }\end{array}$ \\
\hline 15. & $\begin{array}{l}\text { Ulah hitut mun keur gawe di huma serang } \\
\text { 'Jangan kentut kalau sedang bekerja di lahan (ladang)' }\end{array}$ & $\begin{array}{l}\text { Imperatif } \\
\text { Perintah }\end{array}$ \\
\hline 16. & $\begin{array}{l}\text { Teu meunang ngomong nyadok mun gawe di huma serang } \\
\text { 'Jangan berbicara kotor atau kasar kalau sedang bekerja di lahan } \\
\text { (ladang)' }\end{array}$ & $\begin{array}{l}\text { Imperatif } \\
\text { Larangan }\end{array}$ \\
\hline 17. & $\begin{array}{l}\text { Kudu make baju bersih lamun gawe di huma serang } \\
\text { 'Harus menggunakan baju bersih kalau sedang bekerja di lahan } \\
\text { (ladang)' }\end{array}$ & $\begin{array}{l}\text { Imperatif } \\
\text { Perintah }\end{array}$ \\
\hline 18. & $\begin{array}{l}\text { Lamun gawe di huma serang, lalaki kudu make iket } \\
\text { 'Kalau bekerja di lahan (ladang), lelaki harus mengenakan iket' }\end{array}$ & $\begin{array}{l}\text { Imperatif } \\
\text { Perintah }\end{array}$ \\
\hline 19. & $\begin{array}{l}\text { Pare teu meunang dibawa kana motor } \\
\text { 'Padi tidak boleh diangkut dengan motor' }\end{array}$ & $\begin{array}{l}\text { Imperatif } \\
\text { Larangan }\end{array}$ \\
\hline 20. & $\begin{array}{l}\text { Pare teu meunang digiling, kudu ditutu } \\
\text { 'Padi tidak boleh digiling, tetapi harus ditumbuk' }\end{array}$ & $\begin{array}{l}\text { Imperatif } \\
\text { Larangan }\end{array}$ \\
\hline
\end{tabular}


21. Pare teu meunang dihuru

'Padi tidak boleh dibakar atau dibuat kerak'

Imperatif

Larangan

22. Pare teu meunang dipiceun

'Padi tidak boleh dibuang (disia-siakan)'

Imperatif

Larangan

23. Ulah ngajual pare

Imperatif

'Tidak boleh menjual padi'

Larangan

24. Teu meunang maling pare

Imperartif

'Tidak boleh mencuri padi'

Larangan

25. Ulah nyieun sawah

Imperatif

'Tidak boleh membuat sawah'

Larangan

\section{Tabel 2. Ungkapan Tabu dalam dalam Aturan Hidup Bermasyarakat}

\begin{tabular}{|c|c|c|}
\hline No & Ekspresi Ungkapan Tabu & Bentuk Formal \\
\hline 1. & $\begin{array}{l}\text { Ulah make lampu pamarentah } \\
\text { 'Jangan menggunakan listrik (dari pemerintah)' }\end{array}$ & $\begin{array}{l}\text { Imperatif } \\
\text { Larangan }\end{array}$ \\
\hline 2. & $\begin{array}{l}\text { Ulah make jalan hideung } \\
\text { 'Jangan menggunakan jalan aspal' }\end{array}$ & $\begin{array}{l}\text { Imperatif } \\
\text { Larangan }\end{array}$ \\
\hline 3. & $\begin{array}{l}\text { Ulah sakola pamarentah } \\
\text { 'Jangan bersekolah' }\end{array}$ & $\begin{array}{l}\text { Imperatif } \\
\text { Larangan }\end{array}$ \\
\hline 4. & $\begin{array}{l}\text { Lamun gering ulah ka mantri } \\
\text { 'Kalau sakit, jangan berobat ke petugas kesehatan (mantri)' }\end{array}$ & $\begin{array}{l}\text { Imperatif } \\
\text { Larangan }\end{array}$ \\
\hline 5. & $\begin{array}{l}\text { Teu meunang naek motor/mobil } \\
\text { 'Tidak boleh naik motor/mobil' }\end{array}$ & $\begin{array}{l}\text { Imperatif } \\
\text { Larangan }\end{array}$ \\
\hline 6. & $\begin{array}{l}\text { Nyieun imah ulah make paku } \\
\text { 'Membuat rumah jangan menggunakan paku' }\end{array}$ & $\begin{array}{l}\text { Imperatif } \\
\text { Larangan }\end{array}$ \\
\hline 7. & $\begin{array}{l}\text { Nyieun imah ulah ngarusak taneuh } \\
\text { 'Membuat rumah jangan merusak tanah' }\end{array}$ & $\begin{array}{l}\text { Imperatif } \\
\text { Larangan }\end{array}$ \\
\hline 8. & $\begin{array}{l}\text { Teu meunang bohong } \\
\text { 'Tidak boleh bohong' }\end{array}$ & $\begin{array}{l}\text { Imperatif } \\
\text { Larangan }\end{array}$ \\
\hline 9. & $\begin{array}{l}\text { Lamun meuli ulah nawar } \\
\text { 'Kalau membeli (belanja), jangan menawar' }\end{array}$ & $\begin{array}{l}\text { Imperatif } \\
\text { Perintah }\end{array}$ \\
\hline 10. & $\begin{array}{l}\text { Teu meunang make sendal } \\
\text { 'Tidak boleh memakai sandal' }\end{array}$ & $\begin{array}{l}\text { Imperatif } \\
\text { Larangan }\end{array}$ \\
\hline 11. & $\begin{array}{l}\text { Teu meunang boga tivi } \\
\text { 'Tidak boleh memiliki televisi' }\end{array}$ & $\begin{array}{l}\text { Imperatif } \\
\text { Larangan }\end{array}$ \\
\hline 12. & $\begin{array}{l}\text { Panto imah kudu nyanghareup ka utara } \\
\text { 'Pintu rumah harus menghadap ke utara' }\end{array}$ & $\begin{array}{l}\text { Imperatif } \\
\text { Perintah }\end{array}$ \\
\hline 13. & $\begin{array}{l}\text { Ulah make baju atawa kaos } \\
\text { 'Jangan menggunakan baju atau kaos' }\end{array}$ & $\begin{array}{l}\text { Imperatif } \\
\text { Larangan }\end{array}$ \\
\hline 14. & $\begin{array}{l}\text { Teu meunang maling } \\
\text { 'Tidak boleh mencuri' }\end{array}$ & $\begin{array}{l}\text { Imperatif } \\
\text { Larangan }\end{array}$ \\
\hline 15. & $\begin{array}{l}\text { Ulah bohong jeung nipu } \\
\text { 'Jangan bohong dan menipu' }\end{array}$ & $\begin{array}{l}\text { Imperatif } \\
\text { Larangan }\end{array}$ \\
\hline & $\begin{array}{l}\text { Ulah mabok-mabokan } \\
\text { 'Jangan mabuk-mabukan' }\end{array}$ & $\begin{array}{l}\text { Imperatif } \\
\text { Larangan }\end{array}$ \\
\hline
\end{tabular}


17. Teu meunang nyandung

'Tidak boleh beristri lebih dari satu'

Imperatif

Larangan

18. Ulah barang dahar lamun geus sore 'Jangan makan (nasi atau kudapan lain) jika sudah sore'

Imperatif

Larangan

19. Teu meunang make anu sesengitan

Imperatif 'Tidak boleh memakai wewangian'

Larangan

20. Ulah make emas 'Jangan menggunakan emas'

Imperatif

Larangan

21. Ulah ngurusan kebo jeung sapil anu suku opat 'Jangan memelihara kerbau/sapi/binatang berkaki empat'

Imperatif

Larangan

22. Ulah make sabun mun keur mandi 'Jangan menggunakan sabun mandi'

Imperatif

Larangan

23. Ulah make odol lamun nyikat gigi

Imperatif 'Jangan menggunakan pasta gigi'

Larangan

Imperatif Perintah 'Menyimpan baju harus dalam kopek'

Imperatif

Larangan

'Jangan meracuni ikan'

Imperatif

Larangan 'Kalau membuat rumah, jangan ada jendelanya'

Imperatif

Larangan

Imperatif

Larangan Cikeusik'

29. Ulah asup ka tanah larangan 'Jangan masuk ke tanah larangan'

Imperatif Larangan

Imperatif

30. Mun can kawin ulah cacahan 'Kalau belum menikah, jangan berbicara/mengobrol (dengan

Larangan lawan jenis)'

31. Ulah sok nabeng-nabeng gambar di imah

Imperatif 'Jangan suka memasang/menempel gambar-gambar di rumah'

Larangan

32. Ulah ngadoa di kuburan

Imperatif 'Jangan berdoa di kuburan'

Larangan

33. Teu meunang ngaroko

Imperatif

'Tidak boleh merokok'

Larangan

34. Ulah sok pindah agama

Imperatif 'Jangan berpindah agama (keyakinan)'

Larangan 
Tabel 3. Ungkapan Tabu dalam Aturan Pemanfaatan Sumber Daya Hutan dan Lingkungan

\begin{tabular}{|c|c|c|}
\hline No & Ekspresi Ungkapan Tabu & Bentuk Formal \\
\hline 1. & $\begin{array}{l}\text { Teu meunang ngahuma di taneuh titipan } \\
\text { 'Tidak boleh berladang di lahan titipan' }\end{array}$ & $\begin{array}{l}\text { Imperatif } \\
\text { Larangan }\end{array}$ \\
\hline 2. & $\begin{array}{l}\text { Ulah nuar kayu di leuweung titipan } \\
\text { 'Jangan menebang kayu di hutan titipan' }\end{array}$ & $\begin{array}{l}\text { Imperatif } \\
\text { Larangan }\end{array}$ \\
\hline 3. & $\begin{array}{l}\text { Tong maehan sato sagawayah } \\
\text { 'Jangan sembarangan membunuh hewan' }\end{array}$ & $\begin{array}{l}\text { Imperatif } \\
\text { Larangan }\end{array}$ \\
\hline 4. & $\begin{array}{l}\text { Ulah nyieun jalan cai } \\
\text { 'Jangan membuat jalan air (irigasi, bendungan)' }\end{array}$ & $\begin{array}{l}\text { Imperatif } \\
\text { Larangan }\end{array}$ \\
\hline 5. & $\begin{array}{l}\text { Ulah sok ngaratakeun taneuh } \\
\text { 'Jangan meratakan tanah' }\end{array}$ & $\begin{array}{l}\text { Imperatif } \\
\text { Larangan }\end{array}$ \\
\hline 6. & $\begin{array}{l}\text { Ulah asup ka taneuh titipan } \\
\text { 'Jangan masuk ke tanah (hutan) titipan' }\end{array}$ & $\begin{array}{l}\text { Imperatif } \\
\text { Larangan }\end{array}$ \\
\hline 7. & $\begin{array}{l}\text { Teu meunang mawa jelema jangkung ka taneuh titipan } \\
\text { 'Tidak boleh membawa orang yang tinggi (Cina atau bule) ke } \\
\text { tanah titipan' }\end{array}$ & $\begin{array}{l}\text { Imperatif } \\
\text { Larangan }\end{array}$ \\
\hline 8. & $\begin{array}{l}\text { Kabeh taneuh milik karuhun, ulah sa aku-akuna } \\
\text { 'Semua tanah adalah milik leluhur, jangan mengaku-ngaku' }\end{array}$ & $\begin{array}{l}\text { Imperatif } \\
\text { Larangan }\end{array}$ \\
\hline 9. & $\begin{array}{l}\text { Taneuh ulah dijeun undak-undakan } \\
\text { 'Tanah jangan dibuat terasering/sengkedan' }\end{array}$ & $\begin{array}{l}\text { Imperatif } \\
\text { Larangan }\end{array}$ \\
\hline 10. & $\begin{array}{l}\text { Ulah ngebon cengkeh jeung kopi } \\
\text { 'Jangan berkebun cengkih dan kopi' }\end{array}$ & $\begin{array}{l}\text { Imperatif } \\
\text { Larangan }\end{array}$ \\
\hline 11. & $\begin{array}{l}\text { Teu meunang moto taneuh larangani/titipan } \\
\text { 'Tidak boleh memfoto tanah larangan/titipan' }\end{array}$ & $\begin{array}{l}\text { Imperatif } \\
\text { Larangan }\end{array}$ \\
\hline
\end{tabular}

